RESIDENT

\& FELLOW

SECTION

Section Editor

Mitchell S.V. Elkind, MD, MS

Hee Kyung Park, MD Jae-Hong Lee, MD, PhD Myoung C. Lee, MD Sun J. Chung, MD, PhD

Address correspondence and reprint requests to Dr. Sun J. Chung, Department of Neurology, Asan Medical Center, University of Ulsan College of Medicine, 388-1, Pungnap 2-dong, Songpa-gu, Seoul, 138-736, South Korea sjchung@amc.seoul.kr

\section{Teaching NeuroImages: \\ MRI reversal in Wilson disease with trientine treatment}
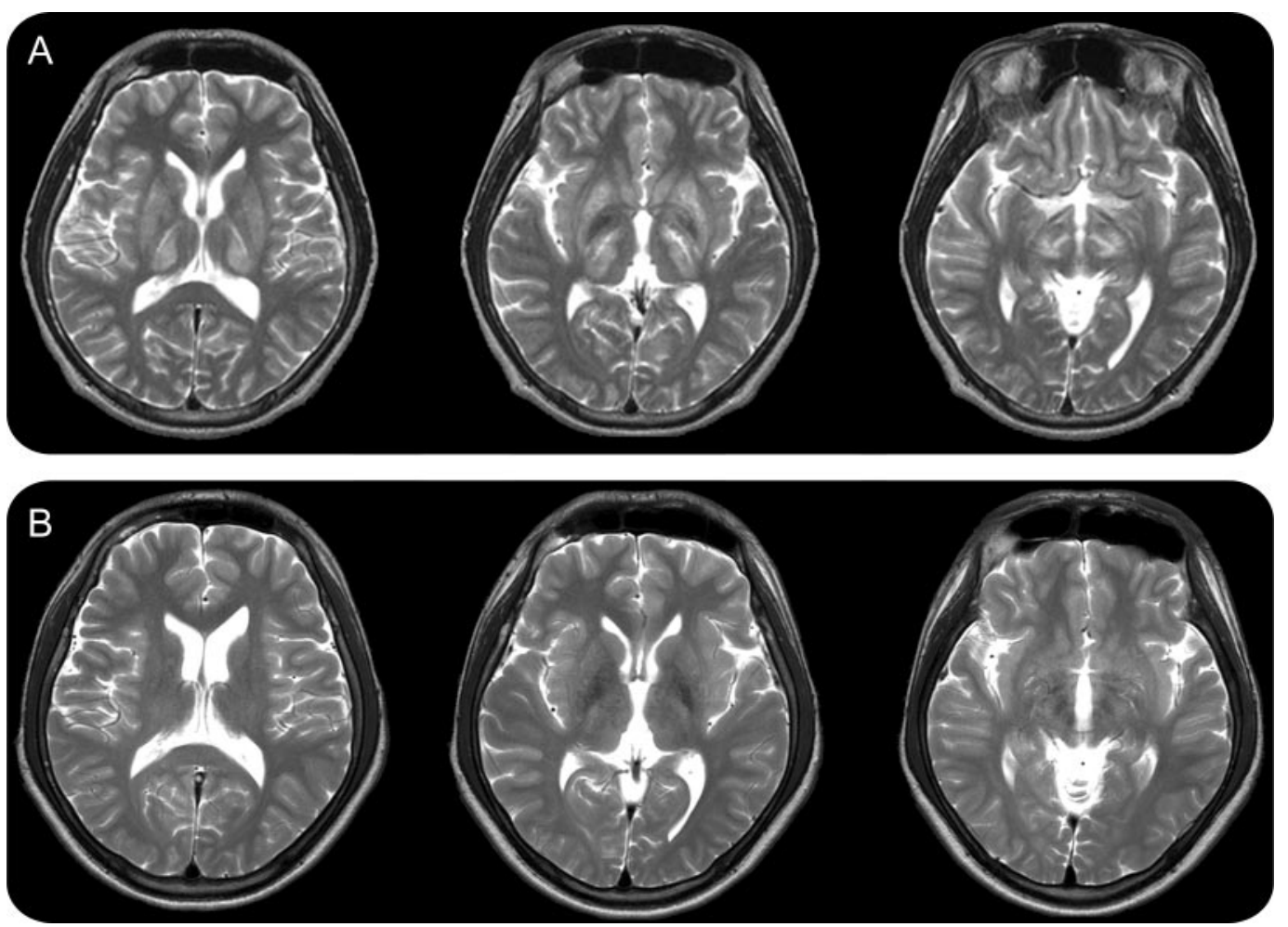

T2-weighted axial images, performed 5 years ago, show bilateral, symmetric hyperintensities in the putamina, thalami, posterior limbs of internal capsules, midbrain, and pons (A). Four years later, the hyperintense lesions are markedly improved (B).

A 17-year-old man presented with severe limb tremor and foot dystonia which had developed 5 years previously. He had no behavioral problems. Brain MRI revealed bilateral, symmetric hyperintensities in the putamina, thalami, and brainstem (figure, A). ${ }^{1}$ Wilson disease was confirmed by the presence of Kayser-Fleischer ring, liver cirrhosis with splenomegaly, low serum ceruloplasmin level, and the mutation (L1083F/N1270S compound heterozygote) of the $A T P 7 B$ gene. Trientine $1,500 \mathrm{mg} / \mathrm{day}$, along with propranolol, levodopa, and clonazepam, were administered. Four years later, his symptoms resolved and brain MRI showed marked improve- ment of the previous lesions (figure, B), which has been rarely reported. ${ }^{2}$ These radiologic findings were well-correlated with clinical improvement, suggesting complete reversibility of the disease with trientine treatment.

\section{REFERENCES}

1. Shivakumar R, Thomas SV. Teaching NeuroImages: face of the giant panda and her cub: MRI correlates of Wilson disease. Neurology 2009;72:e50.

2. Sinha S, Taly AB, Prashanth LK, Ravishankar S, Arunodaya GR, Vasudev MK. Sequential MRI changes in Wilson's disease with de-coppering therapy: a study of 50 patients. Br J Radiol 2007;80:744-749. 


\section{Neurology}

Teaching NeuroImages: MRI reversal in Wilson disease with trientine treatment Hee Kyung Park, Jae-Hong Lee, Myoung C. Lee, et al. Neurology 2010;74;e72

DOI 10.1212/WNL.0b013e3181dad5cc

\section{This information is current as of April 26, 2010}

\section{Updated Information \&} Services

References

Citations

Subspecialty Collections

Permissions \& Licensing

Reprints including high resolution figures, can be found at: http://n.neurology.org/content/74/17/e72.full

This article cites 2 articles, 2 of which you can access for free at: http://n.neurology.org/content/74/17/e72.full\#ref-list-1

This article has been cited by 1 HighWire-hosted articles: http://n.neurology.org/content/74/17/e72.full\#\#otherarticles

This article, along with others on similar topics, appears in the following collection(s):

Dystonia

http://n.neurology.org/cgi/collection/dystonia

Metabolic disease (inherited)

http://n.neurology.org/cgi/collection/metabolic_disease_inherited MRI

http://n.neurology.org/cgi/collection/mri

Information about reproducing this article in parts (figures,tables) or in its entirety can be found online at:

http://www.neurology.org/about/about_the_journal\#permissions

Information about ordering reprints can be found online: http://n.neurology.org/subscribers/advertise

Neurology ${ }^{\circledR}$ is the official journal of the American Academy of Neurology. Published continuously since 1951, it is now a weekly with 48 issues per year. Copyright . All rights reserved. Print ISSN: 0028-3878. Online ISSN: 1526-632X.

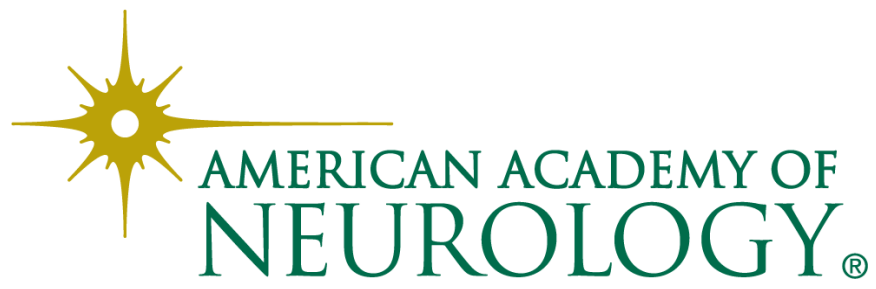

